UDC 615.282:615.451.1:[615.322:582.933:581.45]

\title{
MYCOSTATIC ACTIVITY OF EXTRACTS FROM LEAVES OF PLANTAGO MEDIA L. AND PLANTAGO ALTISSIMA L.
}

\author{
(c) \\ T.V. Khortetska, H.P. Smoilovska, O.K. Yerenko*, O.O. Maliuhina, O.V. Mazulin \\ Zaporizhzhia State Medical University, pr. Mayakovs'koho, 26, Zaporizhzhia, \\ 69035 (Ukraine), e-mail: profesor8707@gmail.com
}

A variety of drugs are widely used to treat fungal infections. Mostly they are products of chemical synthesis, but recently, due to the increased resistance of fungi to many synthetic drugs, the relevance of the use of herbal remedies in the complex treatment of both skin infections and deep mycoses has been increasing. The aim of our research was to study the chemical composition of the lyophilic extracts of Plantago media and Plantago altissima of the flora of Ukraine by HPLC and GLC-MS methods and also mycostatic activity of ethanol and lyophilic extracts of the studied plants. As a result of the research, aucubin iridoid was detected in the lyophilic extracts of both species. There were also detected 15 polyphenolic compounds among which prevails acteoside, plantamayoside, ferulic and chlorogenic acid. Alcohol and lyophilic extracts of $P$. media and $P$. altissima showed mycostatic activity to all studied strains of yeast, dermatophytic fungi and aspergillus. The mycostatic effect of alcoholic extracts of $P$. media and $P$. altissima was more evident in comparison with the mycostatic effect of lyophilic extracts. The most evident antifungal effect was presented by alcoholic extract of $P$. media in relation to the clinical strain of Aspergillus oryzae $(18.0 \pm 1.0 \mathrm{~mm})$, and alcoholic extract of $P$. altissima to the clinical strain of Malassezia sp. $(18.0 \pm 0.5 \mathrm{~mm})$. The data obtained indicate a wide range of mycostatic effects of Plantago media and Plantago altissima extracts and the prospectivity of these objects for practical use in medicine.

Keywords: Plantago media L., Plantago altissima L., bioactive compounds, mycostatic activity.

\section{Introduction}

Fungal infections or mycoses are among the most common infectious diseases that cause damage of skin [1]. However, fungal infections remain a significant cause of morbidity and mortality despite advances in medicine and the emergence of new antifungal agents [2].

A variety of drugs are widely used to treat fungal infections. Mostly they are products of chemical synthesis, but recently, due to the increased resistance of fungi to many synthetic drugs, the relevance of the use of herbal remedies in the complex treatment of both skin infections and deep mycoses has been increasing. Resistance to phytopreparations develops slowly. It is associated with a complex, multicomponent composition and content of organic compounds of various classes with different mechanisms of antifungal action.

Currently, a number of researchers are studying the mycostatic activity of essential oils, aqueous, hydroalcoholic extracts from plant materials containing polyphenols, phenylpropanoids, polysaccharides, sesquiterpene lactones, etc. [1-3].

Advanced objects of modern phytotherapy are representatives of the Plantago L. genus of the Plantaginaceae Juss. family which are traditionally used in medicine in many countries to treat skin diseases, digestive and respira-

Khortetska Taia Volodymirivna - Ph. D., senior lecturer, e-mail:khorttaya@gmail.com

Smoilovska Halina Pavlyvna - Ph. D., Associate Professor, e-mail: smoilovskaj@ukr.net

Yerenko Olena Kostyantynivna- Ph. D, Assistant Professor, e-mail: profesor8707@gmail.com

Mazulin Oleksandr Vladylenovych - D. Sc., Professor, Head of Department, e-mail: mavgnosy@ukr.net

Maliuhina Olena Oleksandrivna - Ph. D, Assistant Professor, e-mail:maluginaea@gmail.com tory system disorders $[4,5]$. Plantago species have analgesic, anti-inflammatory, antimicrobial, antibacterial, anti-fungal, antivirual, antibiotic, antioxidant, hepatoprotective activities, and cytotoxic effect on cancer cells [6-8]. There is an upsurge of interest to Plantago genus due to their therapeutic efficiency and low toxicity effect as compared with the synthetic conventional drugs [9].

\footnotetext{
${ }^{*}$ Corresponding author.
} 
Plantago is the largest genus within the Plantaginaceae family comprising approximately 275 annual and perennial species distributed all over the world [10-12]. In Ukraine the most common species of them are Plantago media L. and Plantago altissima L., the chemical composition of which is characterized by a high content of biologically active substances. About 60 secondary metabolites have been identified during phytochemical studies of Plantago species including phenylethanoid glycosides, triterpenoids, polysaccharides, phenolic acids and other compounds such as alkaloids, caffeic acid derivatives, coumarins, fats and oils, mucilage, polysaccharides, sterols and volatile substances [7, 10, 13-15]. According to various studies, the antimicrobial and mycostatic effect of plantain extracts is associated with the content of phenolic acids, iridoids, flavonoids and saponins [15-17].

The diverse chemical composition of plants of the genus Plantago promote to creation of new herbal medicines, including drug delivery systems, engineering of which requires the improvement of extraction processes [18]. It should be noted that the chemical composition and quantitative content of biologically active substances of most species of the Plantago genus remain poorly understood. Thus, for a comprehensive assessment of lyophilic extracts, it is necessary to determine the qualitative composition and quantitative content of their main components.

The aim of our research was to study the chemical composition of the lyophilic extracts of Plantago media and Plantago altissima of the flora of Ukraine by HPLC and GLC methods and also mycostatic activity of ethanol and lyophilic extracts of the studied plants.

\section{Experimental}

The object of research was air-dry plant material (leaves) of two species of the Plantaginaceae family: Plantago media and Plantago altissima as well as their alcohol and lyophilic extracts. Samples for the study were prepared during the period of mass flowering of the plant (May-August) 2017 in the mixed steppe areas in Zaporizhzhia region. The leaves of flowering plants cut at the soil level were used. Raw materials were dried using a "Termolab" SNOL 24/350 drying chamber at $50{ }^{\circ} \mathrm{C}$. Alcohol extracts $(1: 5)$ were obtained from crushed raw materials using $60 \%$ ethanol by heating in the BV-4 "MICROmed" water bath to $60{ }^{\circ} \mathrm{C}$ for 15 minutes. Extraction was performed twice using new volumes of solvent. Lyophilization of the extracts was carried out under aseptic conditions using the method of freeze-drying from alcoholic extracts of plants using the KS-30 unit (Figer, Czech Republic).

To determine the qualitative composition and quantitative content of polyphenolic components (flavonoids, hydroxycinnamic acids) an HPLC method was used on an Agilent Technologies 1100 chromatograph using a ZORBAX-SB C-18 chromatographic column $(150 \mathrm{~mm} \times 2.1 \mathrm{~mm} \times 3.5 \mathrm{mcm})$. An accurate weighed portion of the plant material was added to a $5 \mathrm{ml}$ measuring tube, filled with $90 \%$ methanol; after this extraction was performed on an UZDN-A1200T unit. The solution was filtered and the analysis was made using 3 types of mobile phases: methyl alcohol $100 \%$, trifluoroacetic acid $0.2 \%$ and a mixture of methyl alcohol $70 \%$ with trichloroacetic acid $0.2 \%$. The flow rate of the mobile phase was $0.25 \mathrm{ml} / \mathrm{min}$, the working pressure was $240-300 \mathrm{kPa}$, the column thermostat temperature was $32^{\circ} \mathrm{C}$, the scan time was $0.5 \mathrm{~s}$, and the wavelength was $\lambda=313-350 \mathrm{~nm}$.

To determine the content of aucubin, the GLC-MS method was used at the Agilent Technology 6890/5973N chromatograph with a $5973 \mathrm{~N}$ mass spectrometric detector adapted for working with capillary columns in a programmed computer mode. An HP-5MS $(\mathrm{l}=30 \mathrm{~m}, \mathrm{~d}=0.32 \mathrm{~mm})$ quartz capillary column was used. The temperature of the thermostat was $50{ }^{\circ} \mathrm{C}$ in the programmed mode $\left(30^{\circ} \mathrm{C} / \mathrm{min}\right.$. up to $\left.220^{\circ} \mathrm{C}\right)$, the carrier gas is helium. The temperature of the detector and evaporator was $250^{\circ} \mathrm{C}$. The carrier gas flow rate was $1.5 \mathrm{ml} / \mathrm{min}$. Sample entry with $1 / 50$ flow separation. Aucubin was identified by determining the retention time of components and a standard sample of the company "Fluka" (Germany) (content $>99.0 \%$ ).

The study of the mycostatic activity of alcohol and lyophilic extracts from plant materials Plantago media and Plantago altissima was carried out in vitro by the bacteriological method using clinical and museum strains of yeast, aspergillus, dermatophytic fungi: Candida albicans (ATCC-885653); Candida utilis (clinical strain); Malassezia sp. (clinical strain); Rhodotorula rubra (clinical strain), Aspergillus oryzae (clinical strain), Aspergillus niger (clinical strain), Microsporum canis (clinical strain), Trichophyton rubrum (clinical strain), Epidermophyton Kaufmann-Wolf (clinical strain).

The antifungal activity of the studied samples was studied on sterile paper disks, previously impregnated with the obtained extracts. For the study, Saburo medium with glucose was used. Disks were added to Petri dishes, which were previously filled up with fungi and yeast. Cultivation was carried out in accordance with the standard of turbidity 10 MO. Evaluation of the results was carried out after $24-48$ hours of incubation in a thermostat at a $36.7^{\circ} \mathrm{C}$. Results were recorded for the corresponding growth inhibition zones. 


\section{Results and discussion}

As a result of the HPLC analysis, in lyophilic extracts a number of organic substances related to polyphenolic compounds was detected. The data on extracts of Plantago media and P. altissima content and their quantitative content are presented in the table 1.

The lyophilic extracts of plantain which we study contain 15 polyphenolic compounds related to flavonoids and hydroxycinnamic acids (phenylpropanoids). In the lyophilic extract of the highest plantain, the presence of phenylpropanoids predominates. Among them the predominant components are acteoside (2.013\%), plantamayoside $(1.723 \%)$, ferulic $(1.526 \%)$ and chlorogenic $(1.386 \%)$ acids. The flavonoid content is less diverse and it is represented by kempferol, luteolin and its derivative, apigenin and its derivative. The lyophilic extract of Plantago media content differs only in the quantitative composition of individual components. It is characterized by a lower content of both hydroxycinnamic acids and flavonoids, especially acteoside (1.022\%) and plantamayoside (1.011\%).

During GLC-MS research of lyophilic extracts, the content for P. media of aucubine was determined to be $1.34 \pm 0.04 \%$, for $P$. altissima to $1.58 \pm 0.05 \%$.

According to previous research the chemical composition of alcohol and lyophilic extracts from the leaves of $P$. media and P. altissima is not significantly different [19].

To study the mycostatic activity of alcohol and lyophilic extracts obtained from leaves of $P$. media and $P$. altissima, yeast fungi, aspergillus, and dermatophytes were used. In each research, the zone of growth inhibition was determined. The results are presented in the table 2.

When studying mycostatic activity in 9 species of fungi, the most significant effect of the Plantago media alcohol extract is determined to be on the clinical strains of Aspergillus oryzae, Malassezia sp. and a museum strain of Candida albicans with inhibition zones ranging from $10.0 \pm 1.0 \mathrm{~mm}$ to $18.0 \pm 1.0 \mathrm{~mm}$. Plantago altissima alcohol extract has fungicidal activity similar to the results for these fungal strains (inhibition zone is in the range from $9.0 \pm 1.5 \mathrm{~mm}$ to $18.0 \pm 0.5 \mathrm{~mm}$ ) with a predominance of suppression of Malassezia sp. (wedge.). The least effective alcohol extracts are in relation to the clinical strains of Epidermophyton Kaufmann-Wolf (inhibition zone $1.1 \pm 0.2$ $\mathrm{mm}$ and $1.0 \pm 0.2 \mathrm{~mm}$, respectively) and Aspergillus niger (inhibition zone $0.8 \pm 0.2 \mathrm{~mm}$ and $0.7 \pm 0.2 \mathrm{~mm}$, respectively). The other fungal species are characterized by low antifungal activity with indicators of suppression of fungal growth from $3.0 \pm 0.5 \mathrm{~mm}$ to $6.0 \pm 1.5$, while the data for Plantago media and Plantago altissima practically did not differ. Lyophilic extracts of the species studied in the experiment showed less mycostatic activity for all strains of fungi. A particularly large decrease in activity is typical for the clinical strain Malassezia sp. (up to $2.0 \pm 0.2 \mathrm{~mm}$ ).

As a result of the study, it was found that the mycostatic effect of the alcoholic extracts of Plantago media and Plantago altissima is more evident in comparison with the mycostatic effect of lyophilic extracts.

The data obtained reveal a wide range of mycostatic effects of extracts of two species of plantain Plantago media and Plantago altissima. At the same time, no correlation was found between the chemical composition and mycostatic activity of the studied extracts. This fact allows us to consider prospectivity of a further in-depth study of this aspect with a view to their practical use.

Table 1. Components of polyphenolic compounds in lyophilic extracts of Plantago media and Plantago altissima

\begin{tabular}{l|c|c}
\hline \multirow{2}{*}{ Polyphenolic compounds } & \multicolumn{2}{|c}{ Content of compounds in lyophilic extracts } \\
\cline { 2 - 3 } & P. altissima $(\%)$ & P. media $(\%)$ \\
\hline Gallic acid & 0.130 & 0.112 \\
Protocatechin acid & 0.127 & 0.067 \\
Plantamayoside & 1.723 & 1.011 \\
Chlorogenic acid & 1.386 & 1.490 \\
Neochlorogenic acid & 0.108 & 0.067 \\
Isochlorogenic acid & 0.118 & 0.064 \\
3-n-coumaroylquinic acid & 0.164 & 0.074 \\
Luteolin-7-O- $\beta$-d-glucopyranoside & 0.531 & 0.713 \\
Ferulic acid & 1.526 & 1.430 \\
Cinnamic acid & 0.109 & 0.093 \\
Luteolin & 0.672 & 0.116 \\
Apigenin & 0.575 & 0.098 \\
Acteoside & 2.013 & 1.022 \\
Kempferol & 0.603 & 0.094 \\
Apigenin-7-O- $\beta$-d-glucopyranoside & 0.162 & 0.074 \\
\hline
\end{tabular}


Table 2. Indicators of research of mycostatic (antifungal) activity of alcohol and lyophilic extracts of Plantago media and Plantago altissima on the clinical and museum strains using the paper disc method

\begin{tabular}{l|c|c|c|c}
\hline \multirow{2}{*}{\multicolumn{1}{c}{ Fungal strains }} & \multicolumn{4}{c}{ Mean zone of inhibition (mm) } \\
\cline { 2 - 5 } & $\begin{array}{c}\text { Alcohol extract } \\
\text { P. media }\end{array}$ & $\begin{array}{c}\text { Alcohol extract } \\
\text { P. altissima }\end{array}$ & $\begin{array}{c}\text { Lyophilic extract } \\
\text { P. media }\end{array}$ & $\begin{array}{c}\text { Lyophilic extract } \\
\text { P. altissima }\end{array}$ \\
\hline \multicolumn{5}{|c}{ Yeast fungi } \\
\hline Candida albicans (ATCC-885653) & $10.0 \pm 1.0$ & $9.0 \pm 1.5$ & $9.2 \pm 1.1$ & $8.9 \pm 0.6$ \\
Candida utilis (clin.) & $6.0 \pm 0.5$ & $6.0 \pm 1.5$ & $6.0 \pm 1.0$ & $5.0 \pm 0.5$ \\
Rhodotorula rubra (clin.) & $3.0 \pm 0.5$ & $3.0 \pm 1.5$ & $2.5 \pm 0.3$ & $2.0 \pm 0.3$ \\
Malassezia sp. (clin.) & $13.0 \pm 0.5$ & $18.0 \pm 0.5$ & $2.8 \pm 0.2$ & $2.0 \pm 0.2$ \\
\hline \multicolumn{5}{|c}{ Aspergillus } \\
\hline Aspergillus niger (clin.) & $0.8 \pm 0.2$ & $0.7 \pm 0.2$ & $0.6 \pm 0.2$ & $0.5 \pm 0.2$ \\
Aspergillus oryzae (clin.).) & $18.0 \pm 1.0$ & $11.0 \pm 1.0$ & $17.4 \pm 1.0$ & $10.0 \pm 1.0$ \\
\hline \multicolumn{7}{|c|}{ Dermatophytes } & $4.4 \pm 0.7$ & $3.0 \pm 0.7$ \\
\hline Microsporum canis (clin.) & $4.4 \pm 0.7$ & $3.0 \pm 0.7$ & $1.0 \pm 0.2$ & $0.9 \pm 0.2$ \\
Epidermophyton Kaufmann-Wolf (clin.) & $1.1 \pm 0.2$ & $1.0 \pm 0.2$ & $3.2 \pm 0.3$ & $3.4 \pm 0.3$ \\
Trichophyton rubrum (clin.) & $4.2 \pm 0.7$ & $4.5 \pm 0.6$ & \\
\hline
\end{tabular}

\section{Conclusions}

1. The composition of the phenolic components of the lyophilic extracts of the two plantain species Plantago media and Plantago altissima and their quantitative content were determined by HPLC method. The plantain extracts which we study contain 15 polyphenolic compounds related to flavonoids and hydroxycinnamic acids (phenylpropanoids). Among them predominates presence of acteoside, plantamayoside, ferulic and chlorogenic acids.

2. The content of aucubin in lyophilic extracts of $P$. media is up to $1.34 \pm 0.04 \%$, $P$. altissima is up to $1.58 \pm 0.05 \%$.

3. Alcohol and lyophilic extracts of Plantago media and Plantago altissima showed mycostatic activity to all studied strains of yeast and fungi. The mycostatic effect of the alcoholic extracts of Plantago media and Plantago altissima was more evident in comparison with the mycostatic effect of lyophilic extracts. The most evident antifungal effect was exerted by Plantago media alcohol extract in relation to the clinical strain of Aspergillus oryzae, and Plantago altissima alcohol extract to the clinical strain of Malassezia sp.

\section{References}

1. Mihyeyev A.O. Zaporizhskyi medychnyi zhurnal, 2017, vol. 19, no. 2 (101), pp. 221-226. DOI: 10.14739/23101210.2017.2.95745. (in Ukr.).

2. Alka J., Padma K., Chitra J. International Journal of Drug Development. \& Research, 2012, vol. 4, no. 3, pp. 92-96.

3. Sharma H., Yunus G.Y., Agrawal R., Kalra M., Verma S., Bhattar S. Indian Journal of Dental Research, 2016, vol. 27, no. 4, pp. 433-436.

4. Lukova P., Karcheva-Bahchevanska D., Dmitrova-Dyulgerova I., Katsarov P., Mladenov R., Iliev I., Nikolova M. Farmacia, 2018, vol. 66, no.4, pp. 609-614. DOI: 10.31925/farmacia.2018.4.8.

5. Lukova P., Dmitrova-Dyulgerova I., Karcheva-Bahchevanska D., Mladenov R., Iliev I., Nikolova M. International Journal of Medical Research and Pharmaceutical Sciences, 2017, vol. 4, no. 6, pp. 20-25. DOI: 10.5281/zenodo.810782.

6. Deribew F., Endale M., Melaku Y. Nat Prod Chem Res, 2018, vol. 6, no. 3, pp. 1-4. DOI: 10.4172/2329-6836.1000315.

7. Vardapetyan Y., Hovhannisyan D., tiratsuyun S., Chailyan G. Journal of Experimental Biology and Agricultural sciences, 2014, vol. 2, no.2, pp. 220-225.

8. Miraj S. Der Pharma Chemica, 2016. vol. 8 (17), pp. 21-25.

9. Farcaș A.D., Moț A.C., Pârvu A.E., Toma V.Al., Popa M.A., Mihai M.C., Sevastre B., Roman I., Vlase L., Pârvu M. Oxid. Med. Cell. Longev., 2019, vol. 2019, article 5049643. DOI: 10.1155/2019/5049643.

10. Najafian Y., Hamedi S.S., Farshchi M. K., Feyzabadi Z. Electron Physician, 2018, vol. 10, no. 2, pp. 6390-6399. DOI: $10.19082 / 6390$.

11. Al-obaidi A.F. Plant arhives, 2018, vol. 18, no. 2, pp. 1859-1864.

12. Beara I.N., Lesjak M.M., Orčić D.Z., Simin N.Đ., Četojević-Simin D.D., Božin B.N., Mimica-Dukić N.M. LWT - Food Science and Technology, 2012, vol. 47, no. 1, pp. 64-70. DOI: 10.1016/j.lwt.2012.01.001.

13. Varban R., Varban D. ProEnvironment, 2012, vol. 5, no. 12, pp. 248-250.

14. Haddadian K., Haddadian K., Zahmatkash M. Indian Journal of Traditional Knowledge, 2014, vol. 13, no. 4, pp. 681685.

15. Budzianowska A., Kikowska M., Malkiewicz M., Karolak I., Budzianowski J. Acta Biologica Cracoviensia s. Botanica, 2019, vol. 61, no. 1, pp. 75-86. DOI: 10.24425/118060. 
16. Deliorman Orhan D., Özçelik B., Hoşbaş S., Vural M. Turkish Journal of Biology, 2012, vol. 36, pp. $672-686$. DOI: $10.24425 / 118060$.

17. Tambur Z., Milošević D.C., Mileusnić I., Doder R., Marjanović M., Selimović B.M., Kulišić Z., Opačić D. Medycyna weterynaryjna, 2018, vol. 74, no. 7, pp. 473-478. DOI: 10.21521/mw.5995.

18. Kalantari A., Kósa D., Nemes D., Ujhelyi Z., Fehér P., Vecsernyés M., Váradi J., Fenyvesi F., Kuki A., Gonda S., Vasas G., Gesztelyi R., Salimi A., Bácskay I. Molecules, 2017, vol. 22, no. 10, article 1773. DOI: 10.3390/molecules22101773.

19. Hortecka T.V. Farmakognostychne doslidzhennya vydiv rodu Plantago L. flory Ukrayiny ta otrumannya substancij krovospynnoyi diyi: Avtoref. dis. ... kand. farm. nauk. [Pharmacognostic study of species of the genus Plantago L. flora of Ukraine and dehydration of hemostatic substances: Abstract. dis. ... Cand. farm. Science]. Zaporizhzhya, 2015, 26 p. (in Ukr.).

Received November 26, 2019

Revised December 19, 2019

Accepted April 7, 2020

For citing: Khortetska T.V., Smoilovska H.P., Yerenko O.K., Maliuhina O.O., Mazulin O.V. Khimiya Rastitel'nogo Syr'ya, 2020, no. 3, pp. 299-303. (in Russ.). DOI: 10.14258/jcprm.2020036779. 
